\title{
The influences of overland flow, stream flow and marine current on As contents in Jiaozhou Bay waters
}

\author{
Dongfang Yang ${ }^{1,2,3, a}$, Fengyou Wang ${ }^{1,2, b, c}$, Sixi Zhu ${ }^{1,2}$, Yunjie $\mathrm{Wu}^{1,2}$ and Xiuqin \\ Yang $^{1,2}$ \\ ${ }^{1}$ Research Center for Karst Wetland Ecology, Guizhou Minzu University, Guizhou Guiyang, \\ Guizhou Guiyang, China; \\ ${ }^{2}$ College of Chemistry and Environmental Science, Guizhou Minzu University, Shanghai, 550025, \\ China; \\ ${ }^{3}$ North China Sea Environmental Monitoring Center, SOA, Qingdao 266033, China. \\ adfyang_dfyang@126.com; ${ }^{b}$ Corresponding author; cwangfy2001@yahoo.com.cn.
}

Keywords: As; Content; Distribution; Pollution level; Pollution source; Jiaozhou Bay

\begin{abstract}
This paper analyzed the contents, distributions and pollution sources of As in Jiaozhou Bay waters in 1983. Results showed As contents ranged from 0.19-4.89 $\mathrm{g} \mathrm{L}^{-1}$,in the whole year, and were lower than Class I for As $\left(20.00 \mu \mathrm{g} \mathrm{L}^{-1}\right)$ in National Standard of China for Seawater Quality (GB3097-1997). There were high value regions in coastal waters in the northeast, east and southwest of the bay, as well as waters outside the bay mouth. The major sources of As were overland flow marine current and stream flow, whose source strengths were 2.93-4.89 $\mu \mathrm{g} \mathrm{L}^{-1}$, 1.59-4.30 $\mu \mathrm{g} \mathrm{L}^{-1}, 1.63-3.33 \mu \mathrm{g} \mathrm{L}^{-1}$, respectively. The variation ranges of the source strengths of the three pollution sources in different seasons ranged from 1.70-1.96 $\mu \mathrm{g} \mathrm{L} \mathrm{L}^{-1}$, indicated that the inputs of As from different sources in this waters was sustained and stable. Hence, in addition to the anthropogenic factors, the natural sources from marine current should be taken into account.
\end{abstract}

\section{Introduction}

As is one of the critical heavy metal which has been widely used in industries and agriculture. A large amount of As-containing waste water was generating along with the rapid increasing of economic after Chinese reform and opening up. Due to the lag of water pollution treatment to the emission load, As pollution has been serious environmental issues in many countries and regions. Being the sink of various pollutants, the marine environment had been polluted by As by means of various pollution sources [1-3]. Understanding the distributions and pollution sources of As was essential. Based on the investigation data on As in Jiaozhou Bay waters in different seasons in 1983, the aim of this paper was to analysis the content, pollution level, distribution, source of As, and to provide theoretical basis for management and remediation of As pollution.

\section{Materials and method}

Jiaozhou Bay $\left(35^{\circ} 55^{\prime}-36^{\circ} 18^{\prime} \mathrm{N}, 120^{\circ} 04^{\prime}-120^{\circ} 23^{\prime} \mathrm{E}\right)$ is located in the south of Shandong Peninsula, eastern China. The area and bay mouth width are $390 \mathrm{~km}^{2}$ and $2.5 \mathrm{~km}$, respectively (Fig. 1). This semi-closed bay is surrounding by cities of Qingdao, Jiaozhou and Jiaonan, respectively. There are more than ten inflow rivers, all of which are seasonal rivers [4-5].

The investigation on As in five sampling sites (H34, H35, H36, H37, H82) in Jiaozhou Bay waters was conducted by North China Sea Environmental Monitoring Center in May, September and October 1983 (Fig. 1). The investigation and measurement of As in waters was follow by National Specification for Marine Monitoring [6]. 


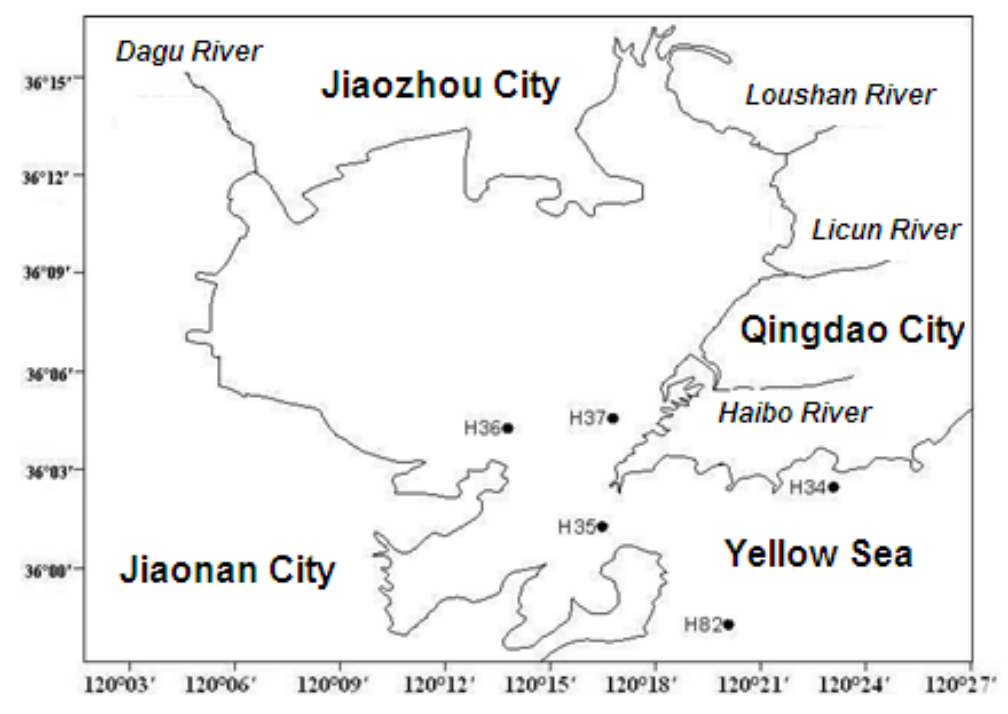

Fig.1 Geography location and sampling sites of Jiaozhou Bay

\section{Results and discussion}

Contents and pollution levels of As. As contents in Jiaozhou Bay waters in May, September and October 1983 were ranged from 1.52-4.89 $\mu \mathrm{g} \mathrm{L}^{-1}, 0.19-1.63 \mu \mathrm{g} \mathrm{L}{ }^{-1}, 0.37-2.93 \mu \mathrm{g} \mathrm{L}^{-1}$, respectively, and were ranged from $0.19-4.89 \mu \mathrm{g} \mathrm{L}^{-1}$ in the whole year.In May, the relative high As contents regions were in coastal waters in the northwest of the bay and waters outside the bay mouth. In September, the relative high As contents regions were in the northwest of the bay and waters outside the bay mouth. In September, the relative high As contents regions were in the northeast and southwest of the bay. However, in according to the guide line of Class I for As (20.00 $\mu \mathrm{g} \mathrm{L}^{-1}$ ) in National Standard of China for Seawater Quality (GB3097-1997), this bay was very slightly contaminated by As in 1983.

Spatial distributions and sources of As. In May, high value of As was occurred in Site H36 (4.89 $\mu \mathrm{g} \mathrm{L}^{-1}$ ), and there was a high value region in the coastal waters in the southwest of the bay, with a series of semi-concentric circles. The contents were decreasing from the high value center to $1.52 \mu \mathrm{g} \mathrm{L}^{-1}$ in the bay mouth (Fig. 2). The was also a high value center (3.33 $\mu \mathrm{g} \mathrm{L}^{-1}$ ) in Site H38 closed to the estuaries of Haibo River and Licun River in the northeast of the bay, and were a series of semi-concentric circles. As contents were decreasing from northeast to the bay mouth $(1.52 \mu \mathrm{g}$ $\left.\mathrm{L}^{-1}\right)$. The third high value center $\left(4.30 \mu \mathrm{g} \mathrm{L}^{-1}\right)$ was in Site H82 outside the bay mouth, and there were a series of gradient parallel lines, indicating that As contents were decreasing from waters outside the bay to the bay center along with the direction of marine current $\left(1.52 \mu \mathrm{g} \mathrm{L}^{-1}\right)$. There was a low value region around Site H35, in where As contents were ranged from 1.52-1.90 $\mu \mathrm{g} \mathrm{L}^{-1}$. In according to the spatial distributions, it could be defined that stream flow and marine current were the major sources of As in May. In September, there was a high value center $\left(1.63 \mu \mathrm{g} \mathrm{L}{ }^{-1}\right)$ in Site H39 closed to the estuaries of Haibo River and Licun River in the northeast of the bay, and there were a series of semi-concentric circles. As contents were decreasing from northeast to the bay mouth $\left(0.19 \mu \mathrm{g} \mathrm{L}^{-1}\right)$. Another high value center $\left(1.59 \mu \mathrm{g} \mathrm{L}^{-1}\right)$ in Site H82 outside the bay mouth, and there were a series of gradient parallel lines, indicating that As contents were decreasing from waters outside the bay to the bay center along with the direction of marine current $\left(0.19 \mu \mathrm{g} \mathrm{L}^{-1}\right)$. There was also a low value region around Site H35, in where As contents were ranged from 0.19-0.40 $\mu \mathrm{g} \mathrm{L}^{-1}$. In according to the spatial distributions, it could be defined that stream flow and marine current were also the major sources of As in September. In October, there was a high value center $\left(2.93 \mu \mathrm{g} \mathrm{L}^{-1}\right.$ ) in Site $\mathrm{H} 36$ in the southwest of the bay, and there were a series of semi-concentric circles. As contents were decreasing from southwest to the north of the bay $(0.37$ $\left.\mu \mathrm{g} \mathrm{L}^{-1}\right)$. Another high value center $\left(1.85 \mu \mathrm{g} \mathrm{L}^{-1}\right)$ was in Site H39 closed to the estuaries of Haibo River and Licun River in the northeast of the bay, with a series of semi-concentric circles, which 
were decreasing from the high value center to the southeast of the bay $\left(0.74 \mu \mathrm{g} \mathrm{L}^{-1}\right)$. Hence, there was also a low value region around Site H35, in where As contents were ranged from 0.19-0.40 $\mu \mathrm{g}$ $\mathrm{L}^{-1}$. In according to the spatial distributions, it could be defined that stream flow and overland flow were the major sources of As in October.

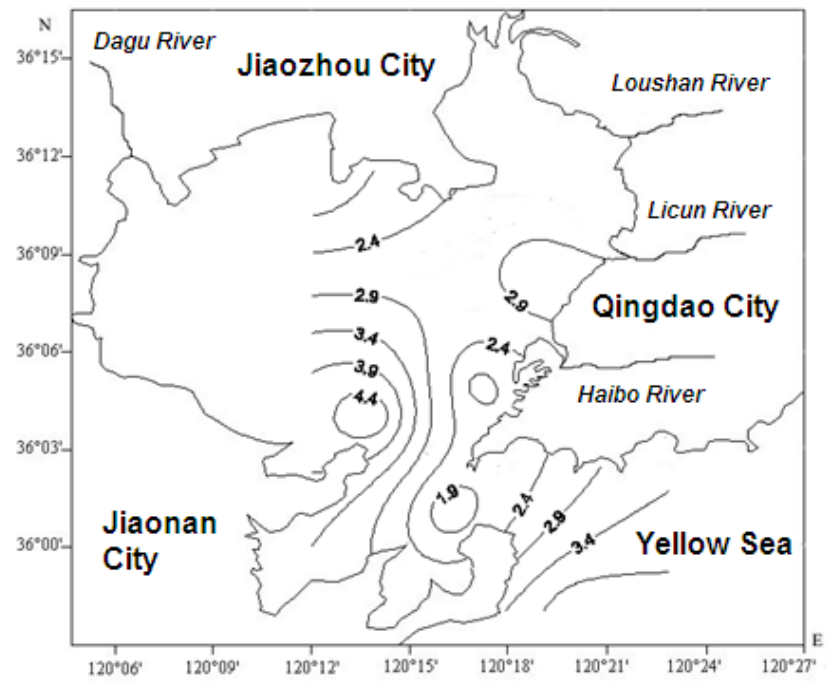

Fig. 2 Spatial distribution of As in surface waters in Jiaozhou Bay in May 1983/ $\mu \mathrm{g} \mathrm{L}^{-1}$

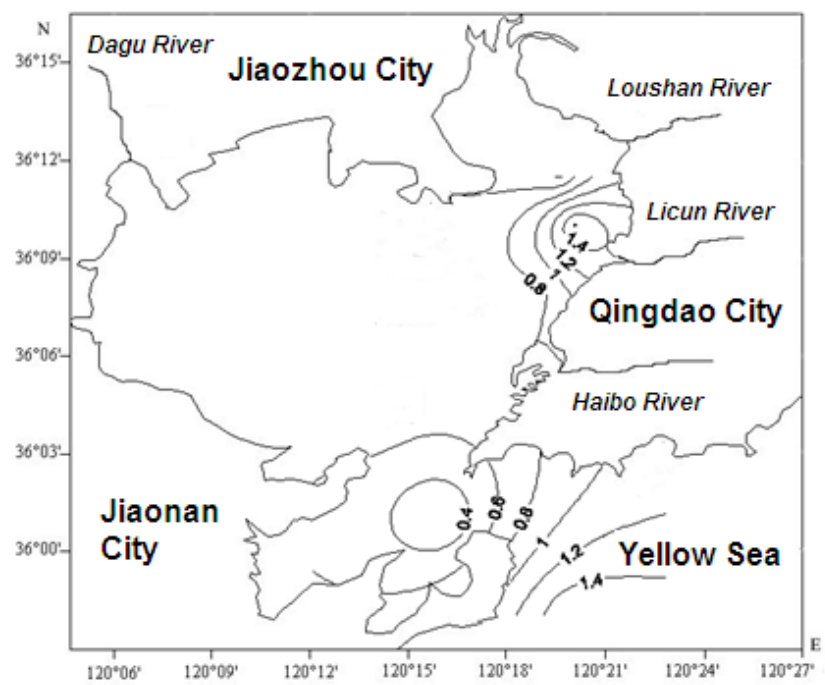

Fig. 3 Spatial distribution of As in surface waters in Jiaozhou Bay in September 1983/ $/ \mathrm{g} \mathrm{L}^{-1}$

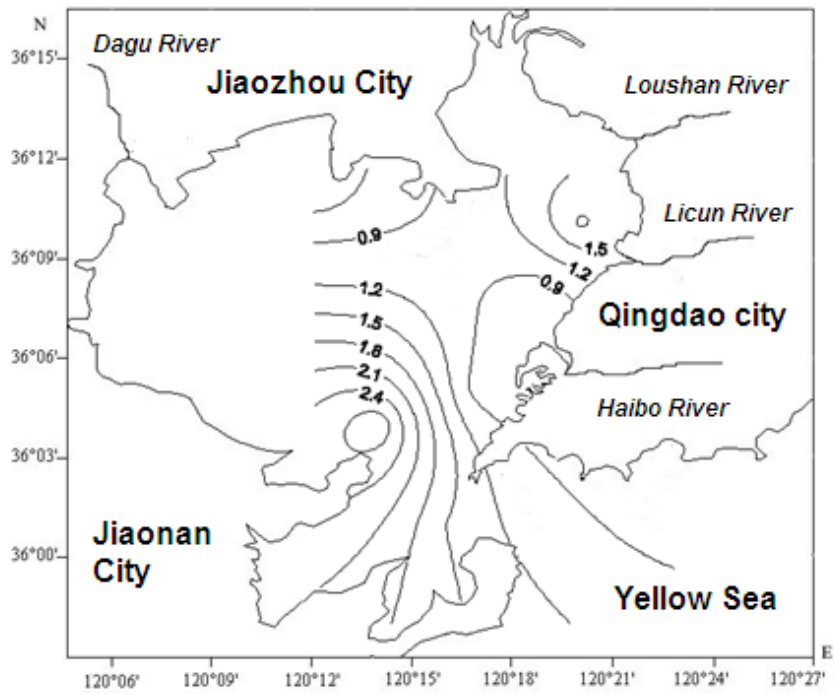

Fig. 4 Spatial distribution of As in surface waters in Jiaozhou Bay in October 1983/ $\mu \mathrm{g} \mathrm{L}^{-1}$ 
Input process of As. In according to the spatial distributions of As in different months, it could be found that the major sources of As in Jiaozhou Bay waters were overland flow, marine current and stream flow, whose source strengths were 2.93-4.89 $\mu \mathrm{g} \mathrm{L}^{-1}, 1.59-4.30 \mu \mathrm{g} \mathrm{L}{ }^{-1}, 1.63-3.33 \mu \mathrm{g} \mathrm{L}^{-1}$, respectively. The variation ranges of the source strengths of overland flow, marine current and stream flow were $1.96 \mu \mathrm{g} \mathrm{L}{ }^{-1}, 1.71 \mu \mathrm{g} \mathrm{L}^{-1}$ and $1.70 \mu \mathrm{g} \mathrm{L}{ }^{-1}$, respectively, indicated that the inputs of As from different sources in this waters was sustained and stable. The source strength of As from overland flow were highest, because As was widely applied in agriculture in study region, and the As-containing overland flow was generated and finally discharged to the bay waters. The source strength of As from marine current were moderate, indicated that the background contents of As in marine environment was high enough to pay attention to. Hence, in addition to the anthropogenic factors, the natural sources from marine current should be taken into account.

\section{Conclusions}

Jiaozhou Bay was very slightly contaminated by As in 1983. The major sources of As in Jiaozhou Bay waters were overland flow, marine current and stream flow, whose source strengths were 2.93-4.89 $\mu \mathrm{g} \mathrm{L}^{-1}, 1.59-4.30 \mu \mathrm{g} \mathrm{L}^{-1}, 1.63-3.33 \mu \mathrm{g} \mathrm{L}^{-1}$, respectively. The variation ranges of the source strengths of overland flow, marine current and stream flow were $1.96 \mu \mathrm{g} \mathrm{L}^{-1}, 1.71 \mu \mathrm{g} \mathrm{L}^{-1}$ and $1.70 \mu \mathrm{g} \mathrm{L}^{-1}$, respectively, indicated that the inputs of As from different sources in this waters was sustained and stable. The source strength of As from overland flow were highest, due to As was widely applied in agriculture in study region. The source strength of As from marine current were moderate, indicated that the background contents of As in marine environment was high enough to pay attention to. Hence, in addition to the anthropogenic factors, the natural sources from marine current should be taken into account.

\section{Acknowledgement}

This research was sponsored by Doctoral Degree Construction Library of Guizhou Nationalities University, Education Ministry's New Century Excellent Talents Supporting Plan (NCET-12-0659), Education Ministry's New Century Excellent Talents Supporting Plan (NCET-12-0659), Project of Outstanding Technological Educators of Governor of Guizhou ([2012]71), Project of Low Carbon Technology Plan of Guiyang (2012205]), Project of Science and Technology Foundation of Guiyang (LKM[2012]05), Special Research Projects of High Level Talents of Guizhou Province (TZJF-2011-44), and Research Projects of Guizhou Nationalities University ([2014]02), Research Projects of Guizhou Province Ministry of Education (KY [2014] 266), Research Projects of Guizhou Province Ministry of Science and Technology (LH [2014] 7376).

\section{Reference}

[1] Yang DF, Song WP, Chen ST, et al.:, Coastal Engineering, Vol. 31(2012), p. 47-55. (in Chinese)

[2] Yang DF, Zhao YH, Pu ZG, et al.: Ocean Development and Management, Vol. 31 (2014), p. 109-112. (in Chinese)

[3] Yang DF, Zhu SX, Wang FY, et al.:Meterological and Environmental Research, Vol. 5(2014), p. 24-26.

[4] Yang DF, Chen Y, Gao ZH, et al.: Chinese Journal of Oceanology and Limnology, Vol. 23 (2005), pp. 72-90.

[5] Yang DF, Wang F, Gao ZH, et al.: Marine Science, Vol. 28 (2004), p. 71-74. (in Chinese)

[6] State Ocean Administration. The specification for marine monitoring: Beijing, Ocean Precess, (1991). 